\title{
Bacterial agglutination studies with secretory IgA prepared from human gastrointestinal secretions and colostrum
}

\author{
D. B. L. MCCLELland, R. R. SAMSON, D. M. PARKIN, AND \\ D. J. C. SHEARMAN
}

From the Gastrointestinal Section of the University Department of Therapeutics, Royal Infirmary, Edinburgh

SUMmARY The function of human purified colostral and gastrointestinal IgA has been studied by its ability to agglutinate common gastrointestinal organisms. Agglutinating activity was unaffected by trypsin or acid but it was abolished rapidly by pepsin. Both colostral and gastrointestinal IgA agglutinated a wide range of enteric organisms. Variations in this activity occurred between different individuals, and between different gastrointestinal sites in the same individual.

In preliminary studies, saliva and IgA prepared from gastric and jejunal secretions in patients with pernicious anaemia showed a more uniform agglutination pattern than IgA prepared from the same sites in other patients. The agglutinin activity of IgA prepared from a particular site may be determined by the bacterial flora at that site.

Agglutination methods for assessing the function of gastrointestinal antibody may be of value in the study of the possible roles of antibodies in inflammatory bowel disease.

It has been known for many years that there is antibody activity in the secretions of the gastrointestinal tract, and there is some evidence that the antibories protect against intestinal infection. Davies (1922) showed specific antibody in stools of patients with dysentery and the studies of Burrows and Havens (1948) showed that gut antibody conferred protection against experimental enteric infection whereas protection correlated poorly with serum antibody titres. Human colostrum has also been shown to contain antibody activity (Sabin and Fieldsteel, 1962; Adinolphi, Glynn, Lindsay, and Milne, 1966; Kenny, Boesman, and Michaels, 1967; Eddie, Schulkind and Robbins, 1971) and this appears to be important in protecting the neonate against enteric infections (Winberg and Wessner, 1971). IgA antibody is likely to be important in this protective role because it represents a large proportion of the immunoglobulin present in both colostrum and gastrointestinal secretions.

It has also been suggested by Beale, Parish, Douglas, and Hobbs (1971) that a further role of IgA antibody in the gastrointestinal tract could be to block the reaction of IgG or IgM with antigens. Such an action might exist to prevent complement-

Received for publication 29 March 1972. fixing reactions which could release substances liable to cause tissue damage in the intestine.

It is therefore important to obtain information about the range of antibody activity in colostrum and gastrointestinal secretions of patients and normal individuals, and this report describes preliminary studies on bacterial agglutination by antibody in colostrum and gastrointestinal secretions. The effect of acid, pepsin, and trypsin on the agglutinating activity has been studied. Because IgA is the predominant class of immunoglobulin in these secretions we have studied purified or semi-purified IgA from these sources. Colostrum was used as the source of $\operatorname{IgA}$ for all initial studies because large amounts of highly purified secretory IgA can be prepared from this source, and it was considered important to carry out preliminary studies on the effect of acid and digestive enzymes on secretory $\operatorname{Ig} A$.

\section{Patients}

Nineteen patients were included in this study. The diagnoses were: pernicious anaemia (7), gastric ulcer (2), adult coeliac disease (2), IgG myeloma (1), macroglobulinaemia (1), biliary gastritis following Polya partial gastrectomy (1), hospital controls with 
no gastrointestinal disease (3), and normal controls (2). Normal pregnant women cooperated in the provision of colostrum.

\section{Materials and Methods}

\section{COLOSTRUM}

A standard mechanical breast pump was used to obtain colostrum from normal women one to three days after delivery.

\section{SALIVA}

Parotid saliva was collected by use of the Curby cap. In some cases mixed oral saliva was used.

\section{GASTRIC JUICE}

Only specimens with a $p \mathrm{H}$ above 6.5 at the time of aspiration were used. These were obtained by aspiration through a nasogastric tube positioned fluoroscopically.

\section{JEJUNAL JUICE}

Samples were obtained using a double-lumened polythene tube of $4 \mathrm{~mm}$ internal diameter with a balloon attached approximately $20 \mathrm{~cm}$ from its distal end. The tube was passed under radiological control until the balloon was in the first part of the duodenum. The balloon was then inflated with a dilute solution of Gastrografin which allowed the tube position to be checked accurately. A nasogastric tube was also passed, the stomach was aspirated, and $50 \mathrm{ml}$ of physiological saline containing $20 \mu \mathrm{Ci}$ of $\mathrm{Cr}^{51}$ was introduced. Gastric content was withdrawn at 10-minute intervals. The jejunal tube was allowed to siphon freely, and aspirate was collected in 10-minute aliquots. All samples were counted in a well-type scintillation counter. No radioactivity was detected in the sample aspirated from the jejunal tube indicating that there was no contamination by gastric juice. In addition, gastric juice samples were screened by thin-layer chromatography for the presence of bile acids. Conjugated bile acid was tested for by the method of Kelly and Doisy (1964) using concentrated alcoholic extracts of gastric juice. Free bile acid was tested for by the method of Hamilton (1963). These methods would have detected the presence of $2 \mu \mathrm{g} / \mathrm{ml}$ of bile acid. Bile acids were not detected in the gastric juice samples in the presence of bile acids in the duodenum. The jejunal juice samples were collected onto ice and Trasylol was immediately added to give a final concentration of 500 units $/ \mathrm{ml}$ of jejunal juice. All samples were stored at $-25^{\circ} \mathrm{C}$ until processed.

BACTERIAL SUSPENSIONS

A panel of 41 intestinal organisms was used (Table
I). These were obtained from patients other than the 19 listed, by jejunal aspirations or from stool cultures. They were identified by biochemical tests using the tables of Edwards and Ewing (1968). Eleven somatic-typed $E$. coli and a number of national collection typed cultures. were also used. The organisms were maintained on nutrient agar slopes. Saline suspensions were prepared from $18-\mathrm{hr}$ cultures and adjusted to an absorbance of 0.08 at $480 \mathrm{~nm}$ using a Hilger Spekker absorptiometer.

\begin{tabular}{ll}
\hline Species & Number of Organisms \\
\hline E. coli (not somatic typed) & 22 \\
E. coli $0 \cdot 1,0 \cdot 2,0 \cdot 4,0 \cdot 5,0 \cdot 6$ & \\
$0 \cdot 7,0 \cdot 9,0 \cdot 11,0 \cdot 18,0 \cdot 39,0 \cdot 75$ & 11 \\
Klebsiella & 3 \\
Proteus & 1 \\
Enterobacter & 1 \\
Pseudomonas aeruginosa & 1 \\
Serratia marcescens & 2 \\
Providencia & \\
\hline
\end{tabular}

Table I Intestinal organisms used in agglutination studies

IMMUNOELECTROPHORESIS

This was performed by the micro method of Scheidegger (1955) using Behringwerke antisera to $\operatorname{IgG}, \operatorname{IgA}$, and $\operatorname{IgM}$ and whole serum and an antiserum to whole human colostrum prepared in rabbits (McClelland, Finlayson, Samson, Nairn, and Shearman, 1971).

\section{IMMUNOGLOBULIN ESTIMATION}

IgA was quantitated by radial immunodiffusion by a modification of the method of Mancini (Fahey and McKelvey, 1965) using rabbit antiserum to $\operatorname{IgA}$ (Behringwerke) and a secretory IgA standard (McClelland et al, 1971). IgG, IgA, and IgM were detected qualitatively by the micro-Ouchterlony method using Hyland Immunoplates and rabbit antisera to $\operatorname{IgG}, \operatorname{IgA}$, and $\operatorname{IgM}$ (Behringwerke).

\section{ANALYTICAL ULTRACENTRIFUGATION}

This was carried out using an MSE analytical ultracentrifuge.

\section{PREPARATION OF IGA FROM HUMAN}

\section{COLOSTRUM}

This was carried out by ion-exchange chromatography followed by two cycles of Sephadex G200 gel filtration, as described by Newcomb, Normansell, and Stanworth (1968) with minor modifications (McClelland et al, 1971). 
PREPARATION OF IGA CONTAINING

FRACTIONS OF GASTRIC AND JEJUNAL JUICE

All samples were centrifuged at $2000 \mathrm{~g}$ for $30 \mathrm{~min}$ to remove debris, and dialysed for $\mathbf{4 8} \mathrm{hr}$ against two changes of distilled water. The samples were then lyophilized, reconstituted in distilled water, and dialysed against Tris-HCl-buffered saline $(0 \cdot 1 \mathrm{M}$ $\mathrm{NaCl}$ in $0.01 \mathrm{M}$ Tris- $\mathrm{HCl}, p \mathrm{H} \mathrm{8.0)}$ before application to a $100 \times 2.5 \mathrm{~cm}$ column of Sephadex G200. The effluents were monitored with an LKB Uvicord U.V. absorptiometer reading at $254 \mathrm{~nm}$, and fractions collected using an LKB Ultrorac fraction collector. With gastric and jejunal samples two peaks of absorbance were found, immunoglobulin being demonstrable by Ouchterlony analysis in the first peak only. Fractions positive for IgG and IgM were discarded and the remaining IgA-containing fractions were pooled, concentrated by negative pressure dialysis, and reapplied to Sephadex G200. The resulting IgA-containing fraction was again concentrated, and on testing contained no IgG or IgM. This material was used in agglutination studies.

PREPARATION OF SALIVA SAMPLES

Saliva was centrifuged, dialysed, and concentrated in the same way as jejunal samples. Even after concentration, IgG and IgM were undetectable in most specimens. These samples were therefore not routinely fractionated on Sephadex G200.

ACID DENATURATION OF IGA

Colostral IgA, in a concentration of $400 \mathrm{mg} / 100 \mathrm{ml}$, was incubated at $37^{\circ} \mathrm{C}$ with an equal volume of $\mathrm{HCl}$ in a concentration of $0.02 \mathrm{M}$. The $p \mathrm{H}$ of the mixture was $2 \cdot 55$. Subsampling was carried out at intervals from $30 \mathrm{sec}$ to $60 \mathrm{~min}$ into an equal volume of $0.02 \mathrm{M}$ $\mathrm{NaHCO}_{3}$. The $p \mathrm{H}$ of all subsamples approximated 7.3. These samples were immediately frozen at $-26^{\circ} \mathrm{C}$. The samples were later tested for agglutinating activity by preparing serial dilutions and incubating with an organism known to be strongly agglutinated by colostral IgA.

TRYPTIC DIGESTION OF IGA

This was performed using bovine, pure crystalline trypsin (Worthington). Colostral IgA was diluted to $400 \mathrm{mg} / 100 \mathrm{ml}$ with $0 \cdot 15 \mathrm{M} \mathrm{NaCl}$ and adjusted to pH 8.0 with $0.01 \mathrm{M}$ tris $\mathrm{HCl}$ buffer to give a final molarity of $0.08 \mathrm{M}, p \mathrm{H} \mathrm{8.0}$. In two separate experiments the enzyme-substrate ratios were 1:50 and 1:10 respectively. Subsampling was carried out at intervals from $5 \mathrm{~min}$ to $24 \mathrm{hr}$ into an equal volume of lima bean trypsin inhibitor (Koch Light) at $p \mathbf{H ~ 7 \cdot 8 . ~}$ The concentration of trypsin inhibitor in the subsample was sufficient to inhibit twice the concentra- tion of trypsin present. All subsamples were immediately frozen at $-26^{\circ} \mathrm{C}$ and later tested for agglutinating activity.

PEPTIC Digestion OF IGA

Crystalline pepsin (Worthington) was used. Colostral IgA was diluted to $400 \mathrm{mg} / 100 \mathrm{ml}$ with isotonic saline. Two separate experiments were performed. In the first experiment, pepsin was used at a concentration similar to that found in the normal adult stomach $(2 \mathrm{mg} / \mathrm{ml})$ (Reizenstein, 1959), giving an enzyme-substrate ratio of $1: 1$, while in the second experiment, the pepsin concentration was chosen to give an enzyme-substrate ratio of $1: 100$. The pepsin solutions were prepared in $0.02 \mathrm{M} \mathrm{HCl}$ and aliquots were added to an equal volume of $\operatorname{IgA}$ solution giving a final $p \mathrm{H}$ of 2.55 . These samples were incubated at $37^{\circ} \mathrm{C}$, and subsamples withdrawn at intervals from $30 \mathrm{sec}$ up to 120 minutes. The subsamples were immediately added to $0.02 \mathrm{M} \mathrm{NaHCO}_{3}$, giving a $p \mathrm{H}$ of approximately 6.8 , and then frozen at $-26^{\circ} \mathrm{C}$ and later tested for agglutinating activity (see Table II).

\section{AGgLUTINATION TESTS}

Tube agglutinations were performed by a standard method (Cruickshank, 1965) using live organisms. Tubes were incubated for four $\mathrm{hr}$ at $37^{\circ} \mathrm{C}$ and then overnight at room temperature. All tubes were read using phase contrast illumination. Autoagglutination controls were set up for all tests and any test was discarded if autoagglutination occurred. Agglutination tests were repeated using organisms which had been heated at $100^{\circ} \mathrm{C}$ for one hour and also in the presence of $2 \%$ D-mannose. Agglutination tests on colostral IgA specimens were tested at concentrations within the physiological range for gastric and jejunal IgA levels. The majority of tests on gastrointestinal samples were performed at an IgA concentration of 20 to $25 \mathrm{mg} / 100 \mathrm{ml}$, and when this concentration was not used this is indicated in the tables. Because of the small total amount of IgA available in the saliva specimens, lower concentrations were used in testing salivary agglutination.

ABSORPTION TEST TO DEMONSTRATE SPECIFICITY OF AGGLUTINATION REACTIONS Suspensions of six test organisms in $0.5 \mathrm{ml}$ volumes were each added to six aliquots of $\operatorname{IgA}(2.5 \mathrm{ml}$, $50 \mathrm{mg} / 100 \mathrm{ml}$ ). The suspensions were incubated for three hr at $37^{\circ} \mathrm{C}$ and centrifuged. Each organism was then tested for agglutination against all the supernates. The final IgA concentration in the test system was $21.5 \mathrm{mg} / 100 \mathrm{ml}$. All the organisms had been previously shown to be agglutinated at this concentration. 


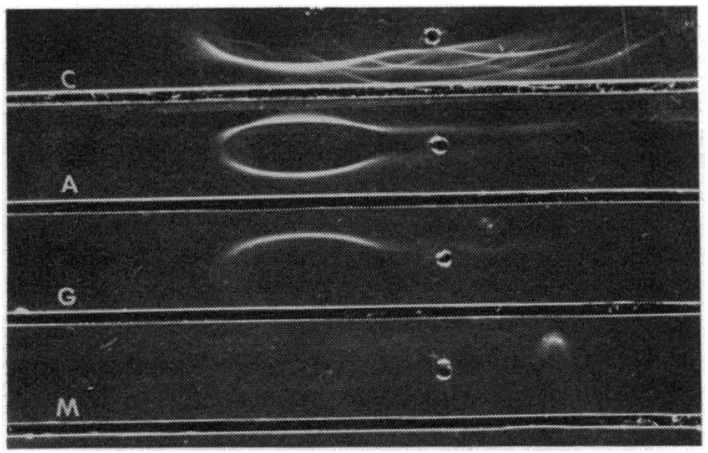

Fig. 1 Immunoelectrophoretic analysis of IgA prepared from human colostrum. Top well contains whole defatted colostrum. Lower three wells contain Ig A preparation. Troughs contain rabbit antisera to human colostrum $(C) \operatorname{Ig} A(A), \operatorname{Ig} G(G), \operatorname{Ig} M(M)$.

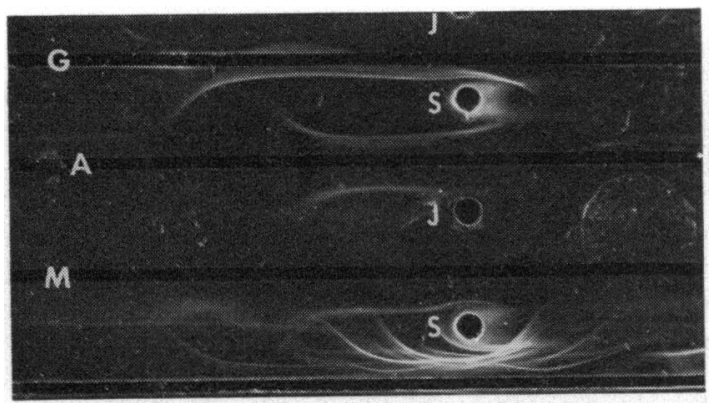

Fig. 2 Immunoelectrophoresis of $\operatorname{Ig} A$ prepared from human jejunal aspirate. Alternate wells contain jejunal $\operatorname{Ig} A(J)$ and pooled normal serum $(S)$. Troughs contain rabbit antiserum to human $\operatorname{Ig} G(G), \operatorname{Ig} A(A), \operatorname{Ig} M(M)$, and whole serum (unlabelled).

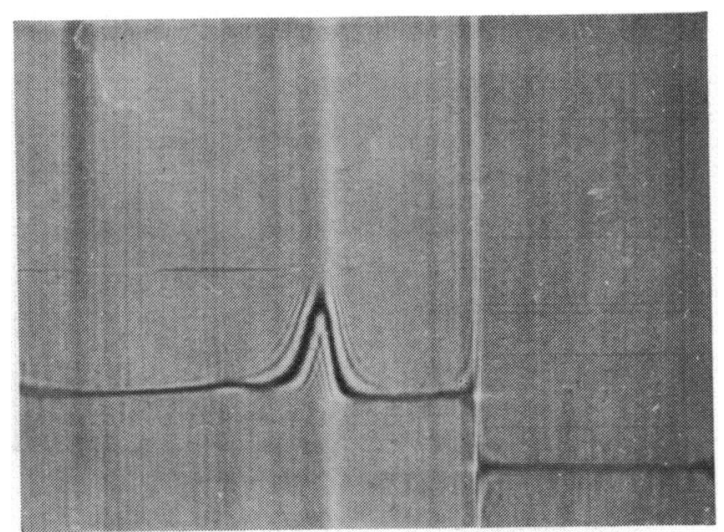

Fig. 3 Analytical ultracentrifuge peak obtained with colostral IgA.
Results

PURITY OF IGA PREPARATIONS

Figure 1 shows an immunoelectrophoretic analysis of the colostral IgA preparation tested at an IgA concentration of $860 \mathrm{mg} / 100 \mathrm{ml}$. A single precipitin arc is seen with antiserum to whole colostrum. A similar arc develops with anti-IgA serum ( $\alpha$ chain specific). No reaction occurs with anti-IgG or antiIgM sera. Figure 2 shows a similar analysis of a representative sample of jejunal fluid after fractionation, tested at an IgA concentration of 270 $\mathrm{mg} / 100 \mathrm{ml}$. A precipitin arc is formed with antiIgA serum. No reaction is seen with anti-IgG or anti-IgM. Figure 3 shows an ultracentrifuge analysis of a colostral IgA specimen showing a single main peak with a sedimentation constant of $10 \cdot 6 \mathrm{~S}$.

\section{BACTERIAL AGGLUTINATION BY COLOSTRAL IGA}

The results are shown in Figure 4. This sample of colostrum was typical, showing a wide variation in its ability to agglutinate the organisms tested, some being agglutinated by IgA concentrations of $0.8 \mathrm{mg} /$ $100 \mathrm{ml}$ while others are not agglutinated at $100 \mathrm{mg} /$ $100 \mathrm{ml}$.

\section{EFFECT OF LOW PH ON AGGLUTINATION BY Colostral IGA}

This was tested with two organisms known to be agglutinated by the IgA specimen used. The results are summarized in Table II indicating that $p \mathrm{H} 2.55$ produces only a slow reduction in agglutinating titre (two dilutions at $30 \mathrm{~min}$ ). Immunoelectrophoretic analysis showed no change in the IgA following incubation at this $\mathrm{pH}$ for $\mathbf{3 0}$ minutes.

\begin{tabular}{lllllll}
\hline $\begin{array}{l}\text { Duration of } \\
\text { Incubation with }\end{array}$ & \multicolumn{7}{l}{ Acid Dilution of Sample } \\
\cline { 2 - 7 } & $N$ & $1 / 2$ & $1 / 4$ & $1 / 8$ & $1 / 16$ & $1 / 32$ \\
\hline Untreated sample & + & + & + & + & + & + \\
Subsamples at: & + & + & + & + & + & - \\
$\mathbf{3 0}$ sec & + & + & + & + & + & - \\
$\mathbf{1}$ min & + & + & + & + & - & - \\
$\mathbf{2}$ min & + & + & + & + & - \\
$\mathbf{3}$ min & + & + & + & + & - & - \\
$\mathbf{4}$ min & + & + & + & - & - & - \\
$\mathbf{5}$ min & + & + & - & - & - & - \\
$\mathbf{1 0}$ min & + & + & + & - & - & - \\
$\mathbf{2 0}$ min & + & + & + & - & - & - \\
$\mathbf{3 0} \mathbf{m i n}$ & + & + & + & - & - & - \\
$\mathbf{m i n}$ & + & + & + & - & - & - \\
\hline
\end{tabular}

Table II The effect of acid on agglutinating activity of secretory $\mathrm{Ig} A$ from human colostrum

The highest concentration tested (N) was $50 \mathrm{mg} / 100 \mathrm{ml}$ before incubation.

$+=$ agglutination

$-=$ no agglutination

Organism: E. coli (code no. 2) 


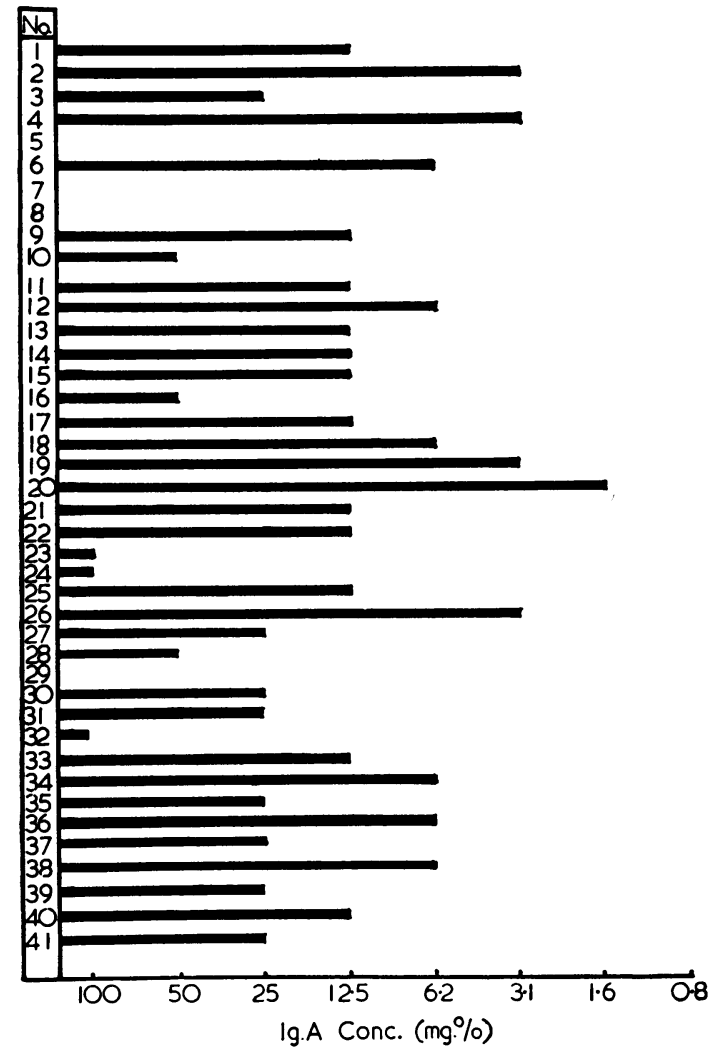

Fig. 4 The figures on the left of the scale represent the laboratory code number of the organisms which are grouped according to biochemical typing. The length of the horizontal bar represents the lowest IgA concentration at which agglutination occurs. The biochemical identifications are as follows: code no. 1-22, E. coli: 23-28, and 37-41, Klebsiella: 29-31, Proteus: 32, 33, Providencia: 35, Serratia marcescens: 36, Aerobacter.

\section{EFFECT OF TRYPTIC DIGESTION ON} AGgLUTINATION BY COLOSTRAL IGA This was tested with the same two organisms. At neither enzyme-substrate ratio tested was there more than a single dilution fall in agglutinating titre, even after 24 hours' incubation. Immunoelectrophoretic analysis showed no alteration compared with untreated IgA.

EFFECT OF PEPTIC DIGESTION ON BACTERIAL AGglutination BY COLOSTRAL IGA

In the experiment using an enzyme-substrate ratio of $1: 1$, pepsin was used at $2 \mathrm{mg} / \mathrm{ml}$, a concentration which simulates the levels found in human gastric juice (Reizenstein, 1959), all agglutinating activity was lost after 30 seconds' incubation.

\begin{tabular}{|c|c|c|c|c|c|c|c|}
\hline \multirow{2}{*}{$\begin{array}{l}\text { Duration of Peptic } \\
\text { Digestion }\end{array}$} & \multicolumn{7}{|c|}{ Dilution of Sample } \\
\hline & $N$ & $1 / 2$ & $1 / 4$ & $1 / 8$ & $1 / 16$ & $1 / 32$ & $1 / 64$ \\
\hline Untreated sample & + & + & + & + & + & + & + \\
\hline \multicolumn{8}{|l|}{ Subsamples at: } \\
\hline $30 \mathrm{sec}$ & + & + & + & - & - & - & - \\
\hline $1 \mathrm{~min}$ & + & + & + & - & - & - & - \\
\hline $2 \mathrm{~min}$ & + & + & + & - & - & - & - \\
\hline $3 \mathrm{~min}$ & + & + & - & - & - & - & - \\
\hline $4 \mathrm{~min}$ & + & + & - & - & - & - & - \\
\hline $5 \mathrm{~min}$ & + & + & - & - & - & - & - \\
\hline $10 \mathrm{~min}$ & + & - & & - & - & - & - \\
\hline $20 \mathrm{~min}$ & + & & & - & & - & \\
\hline $30 \mathrm{~min}$ & + & - & - & - & - & - & - \\
\hline $60 \mathrm{~min}$ & - & - & - & - & - & - & \\
\hline $120 \mathrm{~min}$ & - & - & - & - & - & - & - \\
\hline
\end{tabular}

Table III Effect of peptic digestion on agglutinating ability of secretory $\operatorname{Ig} A$ from human colostrum

The highest concentration tested $(\mathrm{N})$ was $50 \mathrm{mg} / 100 \mathrm{ml}$ before digestion.

$+=$ agglutination

- = no agglutination

Organism tested: $E$. coli (code no. 2)

The results of incubation of $\operatorname{IgA}$ with a 1:100 enzyme-substrate ratio are shown in Table III. Table III shows that the agglutinating titre falls progressively with longer periods of peptic digestion, until after 30 min all agglutinating activity in the solution has disappeared. A very similar result was obtained when this experiment was repeated with another known agglutinable organism.

Immunoelectrophoretic analysis of the peptic digests revealed a double arc in the $\operatorname{IgA}$ region (Fig. 5). This was observable after periods of incubation of up to five minutes. Thereafter, as the reaction proceeded, the arcs became less distinct and were no longer visible after incubation for 30 minutes.

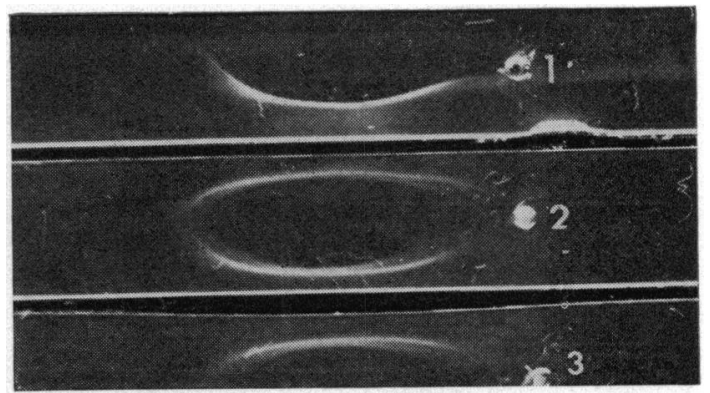

Fig. 5 Immunoelectrophoresis of peptic digest of secretory IgA. Well 1 contains colostral IgA. Wells 2 and 3 contain colostral $\operatorname{Ig} A$ which has been incubated with pepsin for five minutes. The troughs contain rabbit antiserum to human secretory $\operatorname{Ig} A$. 
RESULTS OF TESTS OF SPECIFICITY OF THE AGGLUTINATION REACTION

The effect of $2 \% \mathrm{D}$ mannose on agglutination was minimal. Titres were not affected by more than one tube. This, taken with the absence of autoagglutination, indicated that fimbrial agglutination was not occurring. After heating the organisms at $100^{\circ} \mathrm{C}$ for one hour, no major change in agglutination titre was seen for any organism tested. The maximum change in titre was two tubes. Absorption of antibody activity from colostral IgA was tested using six different organisms (Table IV). Specific absorption of agglutinating antibody was demonstrated by failure of the absorbed serum to agglutinate the homologous organisms, or in two cases, a marked reduction in size of agglutinates formed, with no effect on agglutination of the heterologous organisms.

\begin{tabular}{|c|c|c|c|c|c|c|}
\hline \multicolumn{7}{|l|}{ Organism } \\
\hline \multirow{2}{*}{$\begin{array}{l}\text { Used for } \\
\text { Absorption of } \\
\text { Colostral IgA }\end{array}$} & \multicolumn{6}{|c|}{ Used in Agglutination Test } \\
\hline & E. coli & Klebsiella & E. coli & $\begin{array}{l}\text { Entero- } \\
\text { bacter }\end{array}$ & E. coli & Klebsiella \\
\hline E. coli & - & + & + & + & + & + \\
\hline Klebsiella & + & \pm & + & + & + & + \\
\hline E. coli & + & + & - & + & + & + \\
\hline Enterobacter & + & + & + & - & + & + \\
\hline E. coli & + & + & + & + & \pm & + \\
\hline Klebsiella & + & + & + & + & + & - \\
\hline
\end{tabular}

Table IV Effect of absorption of colostral IgA with six organisms on its ability to agglutinate these organisms

$+=$ strong agglutination

$\pm=$ weak agglutination

$-=$ no agglutination

BACTERIAL AGGLUTINATION BY SAMPLES OF GASTROINTESTINAL SECRETIONS

The pattern of agglutination obtained with the gastric juice samples of 10 patients is shown in Table V. All the gastric juice IgA specimens showed agglutinating activity against the majority of intestinal organisms but there was a wide range of variation in the organisms agglutinated by different samples as shown for example, by Proteus, Enterobacter, or Pseudomonas. Furthermore, although the total number of $E$. coli agglutinated by most of the samples was similar, there were marked differences in the individual organisms agglutinated by each sample. Table VI demonstrates this point by illustrating the results obtained when gastric juice IgA samples were tested against $11 \mathrm{E}$. coli of known O-type. There are wide variations in the pattern of organisms agglutinated by most of the samples although three samples agglutinated all the organisms in this test.

\begin{tabular}{|c|c|c|c|c|c|c|c|c|c|c|}
\hline \multirow{2}{*}{$\begin{array}{l}\text { Organism and } \\
\text { No. Tested }\end{array}$} & \multicolumn{10}{|c|}{ Patient Number } \\
\hline & 1 & 2 & 3 & 4 & 5 & 6 & 7 & 8 & 9 & 10 \\
\hline E. coli (22) & 11 & 11 & 18 & 17 & 10 & 8 & 13 & 15 & 17 & 17 \\
\hline Klebsiella (11) & 9 & 5 & 10 & 10 & 4 & 2 & 6 & 9 & 4 & 6 \\
\hline Proteus (3) & 2 & 1 & 1 & 1 & 1 & 2 & 2 & 2 & 2 & 3 \\
\hline Enterobacter (1) & 0 & 0 & 1 & 1 & 1 & $\mathbf{0}$ & 0 & 1 & 1 & 1 \\
\hline \multicolumn{11}{|l|}{ Pseudomonas } \\
\hline aeruginosa (1) & 1 & $\mathbf{0}$ & 1 & 1 & $\mathbf{0}$ & 1 & 0 & 1 & $\mathbf{0}$ & 1 \\
\hline Serratia marcescens (1) & $\mathbf{0}$ & 0 & 1 & $\mathbf{0}$ & 1 & $\mathbf{0}$ & 1 & 1 & 1 & 1 \\
\hline $\begin{array}{l}\text { Providencia (2) } \\
\text { IgA concentration }\end{array}$ & 1 & $\mathbf{0}$ & 2 & 1 & $\mathbf{0}$ & $\mathbf{0}$ & 1 & 2 & $\mathbf{0}$ & 0 \\
\hline$(\mathrm{mg} / 100 \mathrm{ml})$ & 25 & 25 & 25 & 25 & 25 & 25 & 20 & 24 & 25 & 24 \\
\hline
\end{tabular}

Table V Bacterial agglutination by gastric juice Ig $A^{1}$

${ }^{1}$ Each vertical column represents the results on one patient's gastric juice sample. The figures represent the number of each kind of organism agglutinated by each sample, and may be compared with the total number of each kind of organism tested, as shown on the left.

\begin{tabular}{|c|c|c|c|c|c|c|c|c|c|c|}
\hline \multirow{2}{*}{$\begin{array}{l}\text { O Type of } \\
\text { Organism }\end{array}$} & \multicolumn{10}{|c|}{ Patient Number } \\
\hline & 1 & 2 & 3 & 4 & 5 & 6 & 7 & 8 & 9 & 10 \\
\hline $0 \cdot 1$ & + & - & + & + & - & - & + & + & + & + \\
\hline $0 \cdot 2$ & + & - & + & + & - & + & + & + & + & + \\
\hline 0.4 & + & - & + & + & - & - & + & + & + & + \\
\hline 0.5 & + & - & + & + & - & - & + & + & + & + \\
\hline 0.6 & + & - & + & + & + & - & + & - & + & - \\
\hline 0.7 & + & + & + & + & + & + & + & + & + & + \\
\hline 0.9 & + & - & - & - & + & - & + & - & + & - \\
\hline $0 \cdot 11$ & + & - & + & - & - & - & + & + & + & + \\
\hline 0.18 & + & - & + & + & - & - & + & + & + & nd \\
\hline 0.39 & + & - & + & + & - & - & + & + & + & + \\
\hline 0.75 & + & - & + & + & - & - & + & + & + & + \\
\hline
\end{tabular}

Table VI Agglutination pattern of $11 \mathrm{E}$. coli $O$ types against the IgA-containing fraction of 10 specimens of achlorhydric gastric juice ${ }^{1}$

${ }^{1}$ All samples were tested at an IgA concentration of $25 \mathrm{mg} / 100 \mathrm{ml}$. $+=$ agglutination

- = no agglutination

nd $=$ not done

Similar agglutination patterns were found with IgA prepared from jejunal aspirate (Table VII). This also showed a considerable variation in the organisms agglutinated by individual samples, although the overall total number of the test organisms agglutinated by each sample was similar to that found with gastric juice. Table VIII shows the organisms agglutinated by specimens of saliva from five patients. In three samples tested at an $\operatorname{IgA}$ concentration similar to that in the corresponding jejunal juice IgA sample, a much smaller number of $E$. coli was agglutinated by the saliva than by the jejunal IgA sample.

Table IX compares the agglutinating activity against the 41 non-serotyped organisms of samples taken from two different sites in individual patients and tested at the same IgA concentration. Organisms not agglutinated by either sample are disregarded. The similarity in agglutination pattern produced by 
IgA from the two sites is expressed as a percentage. The greatest tendency for antibody from two sites to agglutinate the same organisms occurs in pernicious anaemia (patients 1,3, and 6) and in a patient with hypochlorhydria (patient 2).

\begin{tabular}{|c|c|c|c|c|c|c|c|c|}
\hline \multirow{2}{*}{$\begin{array}{l}\text { Organism and } \\
\text { No. Tested }\end{array}$} & \multicolumn{8}{|c|}{ Patient Number } \\
\hline & 1 & 10 & 8 & 12 & 13 & 16 & 18 & 19 \\
\hline E. coli (22) & 18 & 10 & 18 & 13 & 17 & 12 & 16 & 16 \\
\hline Klebsiella (11) & 10 & 2 & 10 & 5 & 10 & 7 & 9 & 4 \\
\hline Proteus (3) & 1 & 2 & 2 & 2 & 2 & 3 & 2 & 2 \\
\hline Enterobacter (1) & 1 & 0 & 1 & 1 & 1 & 0 & 1 & 1 \\
\hline $\begin{array}{l}\text { Pseudomonas } \\
\text { aeruginosa (1) } \\
\text { Serratia }\end{array}$ & 1 & 1 & 1 & 1 & $\mathbf{0}$ & 1 & 1 & 1 \\
\hline marcescens (1) & 1 & $\mathbf{0}$ & 1 & 1 & 1 & 1 & $\mathbf{0}$ & $\mathbf{0}$ \\
\hline $\begin{array}{l}\text { Providencia (2) } \\
\text { IgA concentra- } \\
\text { tion }\end{array}$ & 2 & 0 & 1 & 0 & 2 & 1 & 2 & 1 \\
\hline$(\mathrm{mg} / 100 \mathrm{ml})$ & 25 & $16 \cdot 5$ & 20 & 15 & $12 \cdot 5$ & $12 \cdot 5$ & 16 & $16 \cdot 5$ \\
\hline
\end{tabular}

Table VII Bacterial agglutination by jejunal juice $\operatorname{Ig} A^{1}$

${ }^{1}$ Each vertical column represents the results on one patient's jejunal juice sample. The figures represent the number of organisms of each kind agglutinated by each sample, and may be compared with the total number of each kind of organism tested, as shown on the left.

\begin{tabular}{lrrrrr}
\hline Organism and No. Tested & \multicolumn{7}{c}{ Patient Number } \\
\cline { 2 - 7 } & 4 & 14 & 16 & 18 & 19 \\
\hline E. coli (22) & 14 & 16 & 8 & 8 & 8 \\
Klebsiella (11) & 5 & 7 & 2 & 7 & 4 \\
Proteus (3) & 1 & 1 & 2 & 2 & 0 \\
Enterobacter (1) & 1 & 1 & 0 & 1 & 1 \\
Pseudomonas aeruginosa (1) & 1 & 1 & 1 & 1 & 0 \\
Serratia marcescens (1) & 0 & 0 & 0 & 0 & 0 \\
Providencia (2) & 2 & 1 & 1 & 2 & 0 \\
IgA concentration (mg/100 ml) & 6.4 & $8 \cdot 2$ & 12.5 & 16.0 & 16.5 \\
\hline
\end{tabular}

Table VIII Bacterial agglutination by salivary $\operatorname{Ig} A^{1}$ 'Each vertical column represents the results on one patient's saliva.

\section{Discussion}

In the present studies, human colostral secretory IgA was prepared in order to examine the effects of acid and gastrointestinal enzymes on the stability and function of secretory IgA. These preliminary studies could not be performed on the small amounts of secretory $\operatorname{IgA}$ which were obtained from gastrointestinal secretions. Colostral and gastrointestinal secretory IgA appear to have the same structure (Bull, Bienenstock, and Tomasi, 1971) and there is no reason to believe that the results obtained with one cannot be extrapolated to the other.

\section{SPECIFICITY OF AGGLUTINATION}

Previous studies have demonstrated antibacterial antibody in colostrum (Adinolphi et al, 1966; Kenny et al, 1967; Eddie et al, 1971) the antibody being largely or entirely $\operatorname{IgA}$. The present work shows that human colostral IgA has agglutinating activity against a wide range of aerobic intestinal organisms, even when tested at concentrations much lower than those found in whole colostrum. Heating the organism for one $\mathrm{hr}$ at $100^{\circ} \mathrm{C}$ altered the agglutinating titres by 1 or 2 dilutions only, and this indicates that antibody to both $\mathrm{O}$ and $\mathrm{K}$ antigens may be involved. Alternatively, a similar finding would be expected if agglutination was due to antibody to $\mathrm{A}$ antigens. Fimbrial agglutination was considered to be excluded because autoagglutination did not occur and the agglutination titres were not affected by the presence of $2 \% \mathrm{D}$ mannose. The fact that agglutinin activity against one organism could be easily removed from the IgA preparation with no effect on its ability to agglutinate other organisms (Table IV) provided strong evidence that agglutination was due to specific antibody.

\begin{tabular}{|c|c|c|c|c|c|c|}
\hline \multirow[t]{2}{*}{ Patient } & \multicolumn{2}{|c|}{$\begin{array}{l}\text { No. of Bacteria Agglutinated } \\
\text { of Total }\end{array}$} & \multirow{2}{*}{$\begin{array}{l}\text { Similarity between } \\
\text { Agglutination at Two Sites } \\
(x / n \times 100)\end{array}$} & \multicolumn{2}{|l|}{ Gastric Acid Studies } & \multirow[t]{2}{*}{ Diagnosis } \\
\hline & $\begin{array}{l}\text { By One or Both } \\
\text { Samples }(n)\end{array}$ & $\begin{array}{l}\text { By Both } \\
\text { Samples }(x)\end{array}$ & & $\begin{array}{l}\text { Acid Output in } \\
\text { Response to Penta- } \\
\text { gastrin (m-equiv/hr) }\end{array}$ & $\begin{array}{l}\text { Lowest } \mathrm{pH} \text { in } \\
\text { Basal Samples }\end{array}$ & \\
\hline $\begin{array}{l}\mathbf{A} \\
\mathbf{B} \\
\mathbf{C} \\
\mathbf{D} \\
\mathbf{E} \\
\mathbf{F} \\
\mathbf{G} \\
\mathbf{H} \\
\mathbf{I} \\
\mathbf{J}\end{array}$ & $\begin{array}{l}36 \\
37 \\
33 \\
33 \\
32 \\
35 \\
31 \\
29 \\
29 \\
28\end{array}$ & $\begin{array}{r}34 \\
28 \\
28 \\
14 \\
17 \\
24 \\
20 \\
11 \\
7 \\
12\end{array}$ & $\begin{array}{l}95 \\
76 \\
85 \\
43 \\
53 \\
69 \\
65 \\
38 \\
24 \\
43\end{array}$ & $\begin{array}{l}0 \\
1 \cdot 4 \\
0 \\
0 \\
\frac{0}{-} \\
= \\
=\end{array}$ & $\begin{array}{l}7 \\
6 \cdot 8 \\
7 \\
7 \\
1 \cdot 1 \\
7 \\
1 \cdot 1 \\
-1 \cdot 5 \\
1 \cdot 0\end{array}$ & $\begin{array}{l}\text { Pernicious anaemia } \\
\text { No gastrointestinal disease } \\
\text { Pernicious anaemia } \\
\text { IgG myeloma } \\
\text { Normal } \\
\text { Pernicious anaemia } \\
\text { Normal } \\
\text { Normal } \\
\text { Coeliac sprue } \\
\text { Normal }\end{array}$ \\
\hline
\end{tabular}

Table IX Agglutination of 41 organisms by paired IgA samples from stomach and jejunum (patients $A-E$ ) and saliva and jejunum (patients $F-J$ ) 
EFFECTS OF ENZYMES AND ACID ON IGA Several reports indicate that secretory $\operatorname{IgA}$ is more resistant to enzymic digestion than serum IgA. Shim, Yang, Kim, Cho, and Lee (1969) postulated a self-protective antitryptic activity in colostral IgA, while Shuster (1971) compared the pepsin sensitivity of secretory IgA and two classes of IgA myeloma protein, showing that secretory IgA was the more resistant. (These experiments were performed at a $p \mathrm{H}$ of 4.5 with incubation periods up to four hours.) However, when considering the functions of IgA in the intestine, it may be misleading to assess the effect of acid or enzymes on the IgA molecule merely by measuring the change in total amount of $\operatorname{IgA}$ present by a method such as immunodiffusion using specific anti-serum since it is possible that there may be precipitable IgA present which has lost its antigenbinding ability. This is strongly suggested by some of our data. For example, in Table VI the samples from patients 2 and 5 show very little antibody activity against certain organisms despite the fact that IgA was readily detected by immunodiffusion. Both these patients were acid secretors in whom neutral basal samples were tested.

There have been few studies on the effect of acid and enzymic digestion on the function of secretory IgA antibody. Steward (1971) examined the effect of trypsin digestion on the ability of rabbit secretory $\operatorname{IgA}$ to bind ${ }^{125}$ Iodine-labelled albumin and demonstrated that trypsin, although producing partial degradation of $\operatorname{IgA}$ to $5 \mathrm{~S}$ fragments, had little effect on its antigen-binding activity. Kenny et al (1967) found that haemagglutinins in whole human milk were destroyed by $p \mathrm{H} 2$ in 10 to 20 minutes, and that peptic digestion had little effect when carried out at $p \mathrm{H} 4$. The work reported here indicates that colostral IgA agglutinins are markedly resistant to trypsin and acid, although relatively sensitive to pepsin at concentrations found in normal adult gastric juice. We feel that the lower $p \mathrm{H}$ used in our experiments more closely resembles the conditions to which IgA might be subjected in the adult stomach. The neonatal stomach, however, has very little proteolytic activity in the first 20-30 days of life, even when the gastric content is tested at $p \mathrm{H} 2$ (Agunod, Yamaguchi, Lopez, Luhby, and Jerzy Glass, 1969). Our evidence therefore, supports the view that colostral secretory IgA retains its antibody activity in the neonatal gut. In the adult, our data suggest that small intestinal fluid should contain undegraded IgA even if precautions are not taken to neutralize trypticactivity, but that in the normal acid stomach IgA will not be detectable, and this is in agreement with published findings (Douglas, Crabbé, and Hobbs, 1970; McClelland, Finlayson, Samson, Nairn, and Shearman, 1971).
FUNCTIONS OF IgA IN THE GASTRO-

INTESTINAL TRACT

The development of intestinal antibody has been studied in response to bacterial antigens (Eddie $e t$ al, 1971) and viruses (Ogra, Karzon, Righthand, and MacGillivray, 1968; Ogra and Karzon, 1969). We have studied the pattern of antibody to live common intestinal organisms in patients in whom no attempt has been made to induce a response. Thus the results reported give some idea of the normal range of IgA agglutin inactivity in response to common intestinal organisms. No attempt has been made to relate the antibody activity in a given individual to his own flora. The finding of this range of activity in intestinal samples supports the view that the normal production of antibacterial antibody may have a role in the homeostasis of the gut flora. In hypogammaglobulinaemia the pattern of colonization of the intestine may be abnormal even though the total numbers of organisms may not be significantly different from the numbers in control patients (Parkin, McClelland, O'Moore, PercyRobb, Grant, and Shearman, 1972).

The exact function of agglutinating antibody to bacteria in the gut is not yet clear. There is one report (Adinolphi et al, 1966) of complementdependent bactericidal activity in colostral IgA, but this has not been confirmed, and bactericidal action of IgA has not been shown by other workers. A limited amount of work indicates that $\operatorname{IgA}$ is effective in opsonization (Shklair, Rovelstad, and Lamberts, 1969; Wernet, Breu, Knop, and Rowley, 1971). Furthermore, the formation of agglutinates, even in the absence of auxiliary factors such as complement or lysozyme, may reduce an organism's ability to colonize the bowel, possibly by altering the effects of intestinal peristalsis on the organism.

The data available from this study suggest that there may be a correlation between the agglutinin activity of samples taken from different levels of the gastrointestinal tract in some patients. This was observed particularly when the gastric and jejunal samples of two patients with pernicious anaemia and one with hypochlorhydria were compared. In view of the evidence presented that our method of intubation prevented mixing of gastric and jejunal samples, it seems unlikely that the similarity between samples from the two sites was due to contamination. In view of the findings of Ogra and Karzon (1969) it also seems unlikely that stimulation of one site in the gut by bacterial flora would engender production of antibody at another site. A more likely explanation for the similar antibody activity in the stomach and jejunum is that both sites are being stimulated by a similar bacterial flora and it has been shown (Dellipiani and Girdwood, 1964; Gray and Shiner, 
1967) that gastric and jejunal flora are similar in achlorhydric patients. Of the individuals showing no correlation between gastric and jejunal samples, one was a normal volunteer and the other had IgG myeloma. The relative lack of correlation of salivary agglutinins with those in the jejunum in some patients would be entirely in keeping with the widely different bacterial flora of the mouth.

It has been postulated by Beale et al (1971) that defects in the production of IgA antibody could lead to complement-fixing reactions between gut antigens and IgG or IgM which might produce harmful effects. These mechanisms are emphasized by the observation of Eddie et al (1971) that the combination of an IgA antibody with Salmonella typhimurium inhibits the complement-dependent bactericidal effect of IgG or IgM antibodies on that organism. The significance of these observations in relation to infective and inflammatory bowel disease needs further exploration but the methods described here should enable antibody function to be assessed in gastrointestinal disorders.

Drs D. M. Parkin and D. B. L. McClelland were in receipt of Medical Research Council junior research fellowships. We wish to thank Dr M. McA. Lees of the University Department of Obstetrics and Gynaecology, Edinburgh, for arranging the samples of colostrum, and Drs R. R. O'Moore and I. W. Percy-Robb of the University Department of Clinical Chemistry for performing the bile salt determinations.

\section{References}

Adinolphi, M., Glynn, A. A., Lindsay, M., and Milne, C. M. (1966). Serological properties of Gamma A antibodies to Escherichia coli present in human colostrum. Immunology, 10, 517-526.

Agunod, M., Yamaguchi, N., Lopez, R., Luhby, A. L., and Jerzy Glass, G. B. (1969). Correlative study of hydrochloric acid, pepsin and intrinsic factor in newborns and infants. Amer. J. dig. Dis., $14,400-414$.

Beale, A. J., Parish, W. E., Douglas, A. P., and Hobbs, J. R. (1971). Impaired IgA responses in coeliac disease. Lancet, 2, 1198-1200.

Bull, D. M., Bienenstock J., and Tomasi, T. B. (1971). Studies on human intestinal immunoglobulin A. Gastroenterology, 60, 370380.

Burrows, W., and Havens, I. (1948). Studies on immunity to Asiatic cholera. J. infect. Dis., 82, 231-250.

Cruickshank, R. Editor (1965). Mackie and McCartney's Handbook of Bacteriology, 11 th ed. Livingstone, Edinburgh.

Davies, A. (1922). An investigation into the serological properties of dysentery stools. Lancet, 2, 1009-1012.
Dellipiani, A. W., and Girdwood, R. H. (1964). Bacterial changes in the small intestine in malabsorptive states and in pernicious anaemia. Clin. Sci., 26, 359-374.

Douglas, A. P., Crabbé, P. A., and Hobbs, J. R. (1970). Immunochemical studies of the serum, intestinal secretions and intestinal mucosa in patients with adult celiac disease and other forms of the celiac syndrome. Gastroenterology, 59, 414-425.

Eddie, D. S., Schulkind, M. L., and Robbins, J. B. (1971). The isclation and biologic activities of purified secretory IgA and IgG anti-Salmonella typhimurium ' $O$ ' antibodies from rabbit intestinal fluid and colostrum. J. Immunol., 106, 181-190.

Edwards, P. R., and Ewing, W. H. (1968). Identification of Enterobacteriacae, 2nd ed. Burgess, Minneapolis.

Fahey, J. L., and McKelvey, E. M. (1965). Quantitative determination of serum immunoglobulins in antibody-agar plates. J. Immunol., 94, 84-90.

Gray, J. D. A., and Shiner, M. (1967). Influence of gastric pH on gastric and jejunal flora. Gut, 8, 574-581.

Hamilton, J. G. (1963). The effect of oral neomycin on the conversion of cholic acid to deoxycholic in man. Arch. Biochem., 101, 7-13.

Kelly, R. L., and Doisy, E. A., Jr. (1964). Descending thin layer chromatography (TLC) for assay of whole bile. Fed. Proc., 23, 173.

Kenny, J. F., Boesman, M. I., and Michaels, R. O. (1967). Bacterial and viral coproantibodies in breast-fed infants. Pediatrics, 39, 202-213.

McClelland, D. B. L., Finlayson, N. D. C., Samson, R. R., Nairn, I. M., and Shearman, D. J. C. (1971). Quantitation of immunoglobulins in gastric juice by electroimmunodiffusion. Gastroenterology, 60, 509-514.

Newcomb, R. W., Normansell, D., and Stanworth, D. R. (1968). A structural study of human exocrine IgA globulin. J. Immunol., 101, 905-914.

Ogra, P. L., and Karzon, D. T. (1969). Distribution of poliovirus antibody in serum, nasopharynx and alimentary tract following segmental immunization of lower alimentary tract with poliovaccine. J. Immunol, 102, 1423-1430.

Ogra, P. L., Karzon, D. T., Righthand, F., and MacGillivray, M. (1968). Immunoglobulin responses in serum and secretions after immunisation with live and inactivated polio vaccine and natural infection. New Engl. J. Med., 279, 893-900.

Parkin, D. M., McClelland, D. B. L., O'Moore, R. R., Percy-Robb, I. W., Grant, I. W. B., and Shearman, D. J. C. (1972). Intestinal bacterial flora and bile salt studies in hypogammaglobulinaemia. Gut, 13, 182-188.

Reizenstein, P. G. (1959). Effect of digestive enzymes on bound vitamin $B_{12}$. Acta med. scand., 165, 481-486.

Sabin, A. B., and Fieldsteel, A. H. (1962). Antipoliomyelitic activity of human and bovine colostrum and milk. Pediatrics, 29, 105115.

Scheidegger, J. J. (1955). Une micro-méthode de l'immunoélectrophorése. Int. Arch. Allergy, 7, 103-110.

Shim, B. S., Kang, Y. S., Kim, W. J., Cho, S. H., and Lee, D. B. (1969). Self protective activity of colostral IgA against tryptic digestion. Nature (Lond.), 222, 787-788.

Shklair, I. L., Rovelstad, G. H., and Lamberts, B. L. (1969). A study of some factors influencing phagocytosis of cariogenic streptococci by caries-free and caries-active individuals. J. dent. Res., 48, 842-845.

Shuster, J. (1971). Pepsin hydrolysis of IgA-delineation of two populations of molecules. Immunochemistry, 8, 405-411.

Steward, M. W. (1971). Resistance of rabbit secretory IgA to proteolysis. Biochim. biophys. Acta (Amst.), 236, 440-449.

Wernet, P., Breu, H., Knop, J., and Rowley, D. (1971). Antibacterial action of specific IgA and transport of IgM, IgA, and IgG from serum into the small intestine. J. infect. Dis., 124, 223-226.

Winberg, J., and Wessner, G. (1971). Does breast milk protect against septicaemia in the newborn? Lancet, 2, 1091-1094. 